\title{
Accumulation, risk assessment of trace elements in soil-herbage systems and effects of elevation on subalpine grassland in the northeast of Tibet Plateau
}

\author{
Qianfang Yang \\ Lanzhou University \\ Shengli Wang ( $\nabla$ wangshengl@lzu.edu.cn ) \\ Lanzhou University \\ Cuicui Zhao \\ Lanzhou University \\ Zhongren Nan \\ Lanzhou University
}

\section{Research Article}

Keywords: Subalpine grassland, The Tibet Plateau, Ecological risk, Herbage, Heavy metal, Elevation

Posted Date: March 19th, 2021

DOI: https://doi.org/10.21203/rs.3.rs-250384/v1

License: (c) (i) This work is licensed under a Creative Commons Attribution 4.0 International License.

Read Full License 


\section{Abstract}

Ecological environment of remote grassland has become increasingly serious in many countries due to mining, tourism, grazing and other human activities. In this study, a total of 15 pairs of soil-herbage samples were collected in the northeast of the Tibet Plateau to study the relationship between physicochemical properties and content of trace elements in soils and elevation, and to examine the accumulation and fractionation of heavy metals in soil-herbage systems. In addition, the ecological risk of the subalpine grassland was also assessed. The average concentrations of $\mathrm{Hg}, \mathrm{As}, \mathrm{Cu}, \mathrm{Zn}, \mathrm{Pb}, \mathrm{Cd}, \mathrm{Cr}$ and $\mathrm{Mn}$ in soil were higher than their background values of Gansu soil, but the average concentrations of these heavy metals in herbage satisfied Hygienical Standard for Feeds. The speciation analysis of heavy metals in soil indicated that the exchangeable content of heavy metal was very low, except $\mathrm{Pb}, \mathrm{Cd}, \mathrm{Mn}$. There was a linear relationship between $\mathrm{pH}, \mathrm{CaCO}_{3}$, total phosphorus (TP), organic matter (OM), concentrations of $\mathrm{Hg}, \mathrm{As}, \mathrm{Zn}, \mathrm{Pb}, \mathrm{Cr}$ and $\mathrm{Mn}$ in soils, dry weight of herbage and elevation, while there was a quadratic curve trend between $\mathrm{Cu}, \mathrm{Cd}$ in soils and elevation. The results of risk assessment showed that there was no obvious ecological risk in the study area.

\section{Introduction}

Excessive heavy metals in soils are a potential threat to the ecological system and have inspired serious concern due to their persistence and toxicity (Luo et al., 2012; Yang et al., 2014). Contamination of heavy metals in soil leads to their bioaccumulation through the food chain which poses risks to human health (Peralta-Videa et al., 2009; McLaughlin et al., 2000). Soil heavy metal contamination can also cause groundwater contamination through leaching (Mulligan et al., 2001). The analysis of surface soil (0$20 \mathrm{~cm}$ ) is the most valuable for studying heavy metal contamination in grassland (Martin et al., 2017), because anthropogenic heavy metal input usually accumulates in topsoil. Grasses also take up elements predominantly from surface soil (Hou et al., 2014; Kismányoky and Tóth, 2010).

The pollution level of heavy metals in soil mainly depends on its total amount, chemical forms, sources and some soil physical or chemical factors (Chai et al., 2015). Therefore, in the monitoring and assessment of soil pollution, the possible sources of heavy metals in soils should also be distinguished except for the total concentration and chemical speciation of heavy metals as well as some physicochemical parameters (Zhao et al., 2014; Oliva and Espinosa, 2007). The major natural source of heavy metals in soil usually comes from the parent materials (Blaser et al., 2000; Alloway, 1995). It is generally believed that some human activities had a high contribution of heavy metals in soil such as industrial gas emissions (Hovmand et al., 2013), agricultural and industrial waste discharges (Khan et al., 2008; Boularbah et al., 2006), fertilizers and pesticides (Nziguheba and Smolders, 2007).

The elevation gradient influences soil properties and climate (Gaston, 2000), and these factors causes changes of plant community structure and biomass (Dong et al., 2004). On the elevation gradient, the soil properties in different locations may be different due to the differences in temperature, precipitation and parent material. In alpine areas, elevation is one of the most important factors for the micro-climate 
conditions (temperature and precipitation) which determine the growth and distribution of plants (Parmesan, 2006). Even a short geographical distance can lead to significant changes in climate variables such as temperature, precipitation and radiation (Zhang et al., 2013). Elevation not only affects the content of heavy metals in soil during soil formation, but also through long-distance transportation, such as precipitation and atmospheric deposition. However, little work has been done in subalpine grasslands of the Tibet Plateau on the effects of elevation on plant biomass, distribution of soil properties and the contents of trace elements.

According to the national pollution survey bulletin, the over standard rates of cultivated land, forestland, grassland of pollutants in China are $19.4 \%, 10.0 \%$ and $10.4 \%$, respectively, and the over standard rates of $\mathrm{Cd}, \mathrm{As}$ and $\mathrm{Hg}$ are $7 \%, 2.7 \%$ and $1.6 \%$, respectively. China's grassland accounts for $40 \%$ of the total land area, three times that of cultivated land. Grassland is not only a necessary place for grazing, but also a paradise for wildlife. There have been many mining activities and other human activities in the Qilian Mountain (in the northeast of Tibet Plateau), northwest China in recent years. Therefore, it is worth examining the effects of human activities on the soils and herbage in this area.

Whether the environmental quality and herbage quality are at a safe level or affected by human activities has been widely concerned. In order to evaluate the soil and herbage quality of grassland, a study was carried out since August 2018. The aims of this paper were to analyze the relationship between soil physicochemical properties, trace elements content and elevation, to investigate the chemical fractionations of trace elements in soils of a subalpine grassland in the northeast of Tibet Plateau, and to examine the ecological risk of the grassland system.

\section{Materials And Methods}

\subsection{Study area}

The subalpine grassland is located in the middle section of the Qilian Mountains in Sunan county, Gansu, China, which is a remote mountain grassland. And the study area is a part of Qilian Mountain Grassland which is one of the major nature pastures and now is a national tourist attraction. The climate in this area is alpine and semi-arid, and the elevation ranges between 2300 and $5500 \mathrm{~m}$ asl (the snow line is about $4600 \mathrm{~m}$ asl). The average annual precipitation is $433.6 \mathrm{~mm}$, and the annual evaporation is $1488 \mathrm{~mm}$. The average annual sunshine duration is 1893 hours, and the average annual temperature is $5.4^{\circ} \mathrm{C}$ (Cao et al., 2020). In this region, grasslands dominate the south-facing slope aspects, while Qinghai spruce (Picea crassifolia Kom.) forests was on north-facing slope aspects (Cao et al., 2020). Samples were collected in the south-facing slope aspects. The soils on the south-facing and semi-sunny slopes were predominantly sandy textured chestnut soils, and silty-sand textured subalpine meadow soil predominantly developed on the semi-shady slopes, while the north-facing slopes are predominantly silty-sand textured grey cinnamon soils (Qin et al., 2016). The parent materials of soil are various, mainly Aeolian Loess (mainly silt) and rock weathering. The national tourist attraction was divided into three parts, i.e. core area, buffer area and test area. The test area can receive tourists, and the buffer zone has strict restrictions on human 
activities, while the core area does not allow any human activities that are harmful to the environment. The samples in this paper were collected from buffer area and test area. Sampling point locations were shown in Figure 1.

\subsection{Samples collection}

A total of 15 pairs of representative samples were collected, representing different types of human activity areas, different elevation (ranges between 2600 and $3200 \mathrm{~m}$ asl), different terrain, and various special sites. Detailed description of the sampling points was shown in supplementary materials. Soil samples were collected at a depth of $0-20 \mathrm{~cm}$, and the aboveground part of herbage were collected at the same sampling sites in units of one square meter. The soil samples were stored in a polyethylene bag, and plant samples were stored in a cloth bag until transported to the laboratory.

\subsection{Samples analysis}

The soil samples were air-dried at room temperature for two weeks, with one part was ground and sieved through $<2 \mathrm{~mm}$ mesh to measure $\mathrm{pH}$ and electrical conductivity (EC), and the other part was ground and sieved through $<0.149 \mathrm{~mm}$ mesh to measure organic matter, $\mathrm{CaCO}_{3}$ and heavy metal content. The plant samples were classified before analyzing, and then baked at $105^{\circ} \mathrm{C}$ for an hour, baked at $75^{\circ} \mathrm{C}$ to constant weight.

Soil pH and EC were measured in a suspension of 1:2.5 at room temperature using pH meter (PHS-3C, REX, Shanghai, China) and EC meter (DDS-307, REX, Shanghai, China) respectively. OM was determined by Potassium dichromate volumetric method-dilute heating method and the carbonate content $\left(\mathrm{CaCO}_{3}\right)$ in the soil was determined by titration (Lu, 2000).

Soil and plant samples were digested by using microwave digestion system (Anton Paar, Multiwave PRO 3000) (Li et al., 2018). Soil samples of $0.2 \mathrm{~g}$ were digested with the mixture of $\mathrm{HNO}_{3}, \mathrm{HCl}, \mathrm{HF}$ and $\mathrm{H}_{2} \mathrm{O}_{2}$ ( $v / v, 3: 1: 1: 1)$ and plant samples of $0.5 \mathrm{~g}$ were digested with the mixture of $\mathrm{HNO}_{3}$ and $\mathrm{H}_{2} \mathrm{O}_{2}(\mathrm{v} / \mathrm{v}, 4: 1)$ to determine the total $\mathrm{Cu}, \mathrm{Zn}, \mathrm{Pb}, \mathrm{Cd}, \mathrm{Cr}, \mathrm{Mn}$ (Li et al., 2019), while $0.2 \mathrm{~g}$ soil samples or $0.5 \mathrm{~g}$ plant samples were digested with the mixture of $\mathrm{HCl}$ and $\mathrm{HNO}_{3}(\mathrm{v} / \mathrm{v}, 3: 1)$ to determine the total $\mathrm{Hg}$ and $\mathrm{As}$ (Zhang et al., 2018). The Chemical speciation of heavy metals of the soil was obtained using the Tessier sequential extraction procedure (Tessier et al., 1979). Hg and As in soil and plant samples were analyzed by Atomic fluorescence morphology analyzer (AFS-8220, Beijing Jitian, China) and $\mathrm{Cu}, \mathrm{Zn}, \mathrm{Pb}, \mathrm{Cd}, \mathrm{Cr}, \mathrm{Mn}$ were analyzed by AAS (ICE-3500, Thermo, USA).

\subsection{Quality control and assurance}

The reagents and chemicals were of the guaranteed reagent. Reagent blanks, the standard reference soil samples (GSS-8) and plant samples (GSB-24) from the Center of National Standard Reference Material of China were measured in order to monitor the analytical accuracy and precision. Each sample was performed in three replicates. The recoveries of total metals content in standard reference samples were 
within $85 \%$ to $115 \%$. The recovery in Tessier sequential extraction procedure were $88.7 \%-100.3 \%$ for $\mathrm{Hg}$, 90.8\%-97.9\% for As, $90.8 \%-97.3 \%$ for $\mathrm{Cu}, 87.6 \%-98.9 \%$ for $\mathrm{Zn}, 93.8 \%-100 \%$ for $\mathrm{Pb}, 73.1 \%-96.6 \%$ for $\mathrm{Cd}$, $92.0 \%-99.7 \%$ for $\mathrm{Cr}, 97.6 \%-99.8 \%$ for $\mathrm{Mn}$.

\subsection{Bioaccumulation factor (BCF)}

The BCF referred to the ratio of metal concentration in plants to that in soil (Yao et al., 2019) (BCF > 1 indicates heavy metal accumulation). And it was calculated as follows:

$$
B C F=\sigma / C
$$

where $\sigma$ was the concentration of heavy metals in aboveground parts of plants, and $C$ was the concentration of heavy metals in soils.

\subsection{Geo-accumulation index (I geo}

The $I_{\text {geo }}$ can show an idea of the degree of heavy metals contamination in soil. $I_{\text {geo }}$ was calculated using the regional background values (Damiani et al., 1987). The background values were obtained from the Backgrounds of Soil Environment in China (CNEMC, 1990). The I geo values were calculated as follows:

$$
I_{\text {geo }}=\log _{2}\left[C_{n} / 1.5 B_{n}\right]
$$

where $C_{n}$ was the concentration of elements, $B_{n}$ was the geochemical background values of the elements, and 1.5 was used to correct possible variations of the background values for the given elements.

The geological accumulation index was divided into seven levels, $I_{\text {geo }} \leq 0$, indicating no pollution; $0<I_{\text {geo }}$ $<1$, indicating no pollution to moderate pollution; $1<I_{\text {geo }}<2$, indicating moderate pollution; $2<I_{\text {geo }}<3$, indicating moderate pollution to strong pollution; $3<I_{\text {geo }}<4$, indicating strong pollution; $4<I_{\text {geo }}<5$, indicating strong pollution to extreme pollution; $I_{\text {geo }}>5$, indicating extreme pollution.

\subsection{Ecological risk assessment}

The contamination factor (CF) was used to evaluate the contamination status of heavy metals in soil or sediment as an individual index (Williams and Antoine, 2020). Tomlinson et al. (1980) divided the pollution degree into four grades according to the $\mathrm{CF}$ value. CF value $<1$ indicates low contamination, and $1 \leq \mathrm{CF}<3$ and $3 \leq \mathrm{CF}<6$ indicate moderate and considerable contamination, respectively. $\mathrm{CF} \geq 6$ indicates high contamination. The $\mathrm{CF}$ values were calculated as following formula: 
$C F={ }^{C_{i}} / S_{i}$

where $C_{i}$ was the concentration of each element, $S_{i}$ was the geochemical background value of the element.

Potential ecological risk index (RI) was developed by Hakanson (1980) to assess the potential risk of heavy metals in soil to the ecosystem. RI was calculated as follows:

$$
R I=\sum E r=\sum C F \times T_{i}
$$

where $T_{i}$ was the toxicity coefficient, and the coefficients for each metal were $\mathrm{Hg}=40, A s=10, \mathrm{Cu}=5, \mathrm{Zn}$ $=1, \mathrm{~Pb}=5, \mathrm{Cd}=30$ and $\mathrm{Cr}=2$.

It was considered low ecological risk if RI less than 150, and $150 \leq \mathrm{RI}<300$ suggested moderate ecological risk, $300 \leq \mathrm{RI}<600$ suggested considerable ecological risk, $\mathrm{RI} \geq 600$ suggested very high ecological risk.

Nemerow index $\left(P_{N}\right)$ reflects the integrated pollution degree of different heavy metals in the same region (Vu et al., 2017). The $P_{N}$ were calculated by following equations:

$$
P_{N}=\sqrt{\frac{C F_{a v g}^{2}+C F_{\text {max }}^{2}}{2}}
$$

where $\mathrm{CF}_{\text {avg }}$ and $\mathrm{CF}_{\text {max }}$ were the average and the maximum of $\mathrm{CF}$. Standards for grading metals contamination were as follows: uncontaminated $\left(P_{N} \leq 1\right)$, slightly contaminated $\left(1<P_{N} \leq 2.5\right)$, moderately contaminated $\left(2.5<P_{N} \leq 7\right)$, and heavily contaminated $\left(P_{N}>7\right)$ (Yuan et al., 2020).

\section{Results And Discussion}

\subsection{Multivariate statistical analysis}

\subsubsection{Physicochemical properties and heavy metal concentrations.}

The average contents of heavy metals in plants were compared with the Hygienical standard for feeds (CNSBQTS, 2017). As shown in the Table 1, the concentrations of heavy metals in herbage were far lower than the standard contents, indicating that the concentrations of heavy metals in herbage in this area were at a safe level, which was suitable for grazing. 
The $\mathrm{pH}$ of soils ranged from 7.9 to 8.2 with an average value of 8.1 (Table 2). EC in soils was within the range of $165-282 \mu \mathrm{sm}^{-1}$ and with an average of $215 \mu \mathrm{s} \mathrm{cm}^{-1}$. The EC in soil reflects the content of soluble salt directly. High EC value could affect microbial community and herbage growing. $\mathrm{CaCO}_{3}$ contents in soils ranged from 43.39 to $183.45 \mathrm{~g} \mathrm{~kg}^{-1}$, with a mean value of $68.48 \mathrm{~g} \mathrm{~kg}^{-1}$. Calcium carbonate in soil was one of the main factors of alkalinity $(\mathrm{pH}>7)$. OM in soils ranged within 48.77 $160.79 \mathrm{~g} \mathrm{~kg}^{-1}$ with a mean value of $88.68 \mathrm{~g} \mathrm{~kg}^{-1}$ which was higher than the background.

The mean values of $\mathrm{Hg}, \mathrm{As}, \mathrm{Cu}, \mathrm{Mn}, \mathrm{Cd}, \mathrm{Zn}, \mathrm{Pb}, \mathrm{Cr}$ were $40.9 \pm 10.8 \mu \mathrm{g} \mathrm{kg}^{-1}, 13.2 \pm 1.3 \mathrm{mg} \mathrm{kg}^{-1}, 34.0 \pm 2.1$ $\mathrm{mg} \mathrm{kg}^{-1}, 876 \pm 159 \mathrm{mg} \mathrm{kg}^{-1}, 0.232 \pm 0.057 \mathrm{mg} \mathrm{kg}^{-1}, 81 \pm 16 \mathrm{mg} \mathrm{kg}^{-1}, 34.8 \pm 7.3 \mathrm{mg} \mathrm{kg}^{-1}, 136.6 \pm 31.6 \mathrm{mg}$ $\mathrm{kg}^{-1}$ respectively. The mean values of heavy metals were lower than the Environmental Quality Standard for Soil (CNEPA,1995) except Cd and Cr. All of the mean values of metals in soils were higher than their background values of Gansu Province soil (CNEMC, 1990), suggesting that heavy metal concentrations in the studied soils were affected by human activities, but not leading to a significant contamination of soils. The coefficient variations (CV) of heavy metals were comparatively low, suggesting that the concentrations levels of these heavy metals in soils were less variable, and the extrinsic inputs of the metals into the soils were limited.

\subsubsection{Correlation analysis}

The results of correlation analysis were shown in Table 3. For soil physicochemical properties, $\mathrm{pH}$ showed a positive correlation with $\mathrm{Pb}$, indicating that neutral-alkaline soil was good for the accumulation of lead in soil. EC showed a significant positive correlation with mercury $(r=0.528, p<0.05)$ but negative with arsenic $(r=-0.600, p<0.05)$. The reason might be that the properties of mercury and arsenic were different. $\mathrm{Hg}$ was positively charged and As was negatively charged. It was also revealed that soluble salts might reduce arsenic concentration. OM showed a negative correlation with arsenic $(r=-0.546, p<$ 0.05), contrary to the results of some other researchers (Quenea et al., 2009), which might be caused by regional differences. $\mathrm{CaCO}_{3}$ content correlated positively with $\mathrm{Cd}(\mathrm{r}=0.656, \mathrm{p}<0.01)$, indicating that calcium carbonate promotes the accumulation of $\mathrm{Cd}$ in soil, which also confirmed that cadmium and calcium may have similar properties. $\mathrm{Hg}, \mathrm{As}, \mathrm{Cu}, \mathrm{Mn}, \mathrm{Cd}, \mathrm{Zn}, \mathrm{Pb}$ and $\mathrm{Cr}$ were not significantly correlated with each other, implying that the sources of these heavy metals were different.

\subsubsection{Relationship between elevation and soil physicochemical properties}

Elevation was the most important factor affecting the abiotic environment by changing climatic and topography (Holechek et al., 2010, Roukos et al., 2017). Most subalpine grasslands were on steep slopes, both elevation and degree of slope influenced plant diversity and soil properties (Hadjigeorgiou et al., 2005, Roukos et al., 2011).

Linear regression analysis (Figure 2) showed that the contents of $\mathrm{CaCO}_{3}$ and TP decreased significantly with the increase in elevation, while the contents of soil organic matter increased significantly with the 
increase in elevation. EC and herbage had a positive correlation with elevation, while $\mathrm{pH}$ had a negative correlation with elevation, but this trend was not very obvious.

The decrease in $\mathrm{CaCO}_{3}$ content with the increase of elevation could be due to the increase in soil organic matter and water content (Ali et al., 2019). The difference in soil parent material and small area climate might also be the reasons. The change of $\mathrm{pH}$, temperature and precipitation also affected the change of $\mathrm{CaCO}_{3}$ with elevation (Ali et al., 2017), because acidity, temperature and precipitation affected the solubility of $\mathrm{CaCO}_{3}$.

The change of $\mathrm{OM}$ with elevation was mainly related to temperature and plant density. Lower temperature delays decomposition of OM (Charan et al., 2012), because low temperature reduces soil enzyme activity. As the main source of organic matter, the vegetation material also had a positive relationship with vegetation density (Williams et al., 2003). The plant yield in the study area increased with the increase in elevation. However, the content of soil organic matter at low elevation was still higher than that at high elevation in this study, which could be because of grazing in the study area. Grazing was more frequent at higher elevation (more than $3000 \mathrm{~m}$ asl) in this area, and as a result, the enrichment efficiency of organic matter in soil was greatly reduced. Total Kjeldahl nitrogen (TKN) had almost no linear correlation with elevation, which was consistent with Cao et al (2020). But there was a significant negative correlation between TP and elevation. This could be caused by the dissolution of soil soluble phosphorus into rainwater and its downward migration along the slope (Roberts and Bettany, 1985). In addition, soil water content, phosphorus adsorption capacity, $\mathrm{pH}$ value and the interaction among microclimate, topography and vegetation might also cause the change of soil total phosphorus with elevation (He et al., 2016).

\subsubsection{Relationship between elevation and soil trace element}

Elevation was one of the factors affecting the distribution of heavy metals in subalpine grassland soil. Affected by elevation, the precipitation increased with the increase in elevation. When the elevation reached a certain level, the precipitation decreased and the total deposition might be changed (Salerno et al., 2015; Reiners et al., 1975). The Figure 3 showed that except for $\mathrm{Cu}$ and $\mathrm{Cd}$, the content of other trace elements was linear with elevation.

The concentration of $\mathrm{Hg}, \mathrm{Zn}$ and $\mathrm{Cr}$ increased with elevation, while that of $\mathrm{As}, \mathrm{Pb}, \mathrm{Mn}$ decreased. $\mathrm{Hg}$, in the forms of $\mathrm{Hg}^{0}$, gaseous oxidized $\mathrm{Hg}$, and particulate phase mercury (Grigal, 2002), can undergo longrange atmospheric transport, due to its volatilization and persistence in the environment. Then, $\mathrm{Hg}$ entered the soil through precipitation or atmospheric deposition, which might be one of the reasons for the positive correlation between $\mathrm{Hg}$ and elevation. The change trend of $\mathrm{Zn}$ and $\mathrm{Cr}$ were similar to that in Magnani et al. (2018), but Mn and Pb were not the same to some studies (Magnani et al., 2018; McGee and Vallejo, 1996; Reiners et al., 1975). As a matter of fact, in addition to air pollution, topographic conditions and microclimate also affect the distribution of heavy metals (Bergamasch et al., 2002; Cong et al., 2015). Several studies in Alps showed that deposition was increased with elevation (Camarero et 
al., 2009), but it was not found in other studies (Kang et al., 2007). The non-linear changes of Cu and Cd indicated that these two elements might be affected by many factors, such as human activities, atmospheric deposition, topographic conditions and parent materials. As a metalloid, the concentration of arsenic was affected by many factors, such as $\mathrm{pH}$, speciation (arsenate, arsenite), organic matter, etc (Cai et al., 2002; González et al., 2006). In this study, arsenic concentration and organic matter showed a significant negative correlation, indicating that arsenic was more affected by organic matter concentration, which was different from the results of González et al. (2006).

\subsubsection{BCFs in herbage}

As shown in Table 2, $\mathrm{Hg}, \mathrm{Cd}$ and $\mathrm{Zn}$ were the most translocated metals. BCFs were in the decreasing order of $\mathrm{Hg}(0.417)>\mathrm{Cd}(0.393)>\mathrm{Zn}(0.302)>\mathrm{Cu}(0.181)>\mathrm{Mn}(0.087)>\mathrm{Pb} \otimes 0.021 \rrbracket>\mathrm{As}(0.019)>\mathrm{Cr}(0.004)$. There were many factors to control the accumulation and bioavailability of heavy metals, including: sequestration and speciation, active/passive transfer processes, redox states and the response of plants to elements in relation to seasonal cycles (Badr et al., 2012). Soil structure and texture also affected the absorption of heavy metals by herbage. Unlike other elements, $\mathrm{Zn}$ occurs in the soil frequently in easily soluble forms (Gawryluk et al., 2020) and Zn is usually accumulated the most in the aboveground tissues of plants in an ecosystem where this element occurs in the air (Kabata-Pendias and Pendias, 2001).

All BCFs in this study were less than 1, indicating that heavy metals were not accumulated excessively in plants. It was worth noting that the BCF of mercury, cadmium and zinc in herbage in the study area reached 0.3. Although the concentration of heavy metals in herbage was at a safe level, the concentration of these three metals in soil should be monitored.

\subsection{Assessment of ecological risk}

\subsubsection{Geo-Accumulation Index}

The $\mathrm{I}_{\text {geo }}$ of $\mathrm{Hg}, \mathrm{Cd}$ and $\mathrm{Cr}$ in most samples reached level 1 to 2 (Table 4), indicating that $\mathrm{Hg}, \mathrm{Cd}$ and $\mathrm{Cr}$ in the soil of the study area were more obviously affected by human activities compared with other metals. And $93 \%$ samples reached level 1 of $\mathrm{Pb}, 33 \%$ samples reached level 1 of $\mathrm{Mn}$, and the other samples were level $\mathrm{O}$, implying that $\mathrm{Pb}, \mathrm{Mn}$ in the soil slightly affected by human activities. As, $\mathrm{Zn}$ and $\mathrm{Cu}$ in soil were almost not affected by human beings, because almost all samples were evaluated at level 0 .

Qilian Mountain was rich in mineral resources (Qin et al., 2016). According to the survey, there were some mining sites around the study area. Although some of the mining sites were closed at the request of the government, the impact on the soil quality directly or through atmospheric subsidence was long-term. The behavior of herdsmen in the process of grazing, other human activities such as traffic in the scenic area may be the main reason that the metal content in the soil in the study area was higher than the background value.

\subsubsection{Potential ecological risk index and Nemerow pollution index}


The contamination level of single element was generally low, and most CF values were ranged from 1 to 3 (Table 5), which indicated that they were at moderate contamination and the impact of human activities was limited (Williams and Antoine, 2020). Arsenic, zinc, copper and manganese in most sampling sites reached moderate contamination. The sites with high zinc ecological risk were concentrated in areas with high elevation, which were mainly affected by grazing activities, while the sites with high ecological risk of arsenic were concentrated in the areas with low altitude, and the human impact was relatively less frequent. The higher ecological risk of mercury in high elevation areas might be related to the migration characteristics of mercury. It was well known that mercury could migrate with the atmosphere and enter the soil with precipitation and atmospheric deposition. The higher precipitation in high elevation in study area made the soil more likely to enrich mercury. As mentioned above, plant biomass in the study area increased with elevation, and higher plant density might have a positive effect on mercury interception in precipitation.

In terms of RI (Table 6), 5 sampling sites had RI values lower than 150, indicating low ecological risk, and other sampling points were in the range of 150-300, which implying that the ecological risk was moderate. The maximum RI value was 227.31 (S8 sampling site), which was still far below the upper limit value of moderate risk. The results showed that most of the study area was affected by human activities, but it had no serious impact on the ecological environment.

The calculated $\mathrm{P}_{\mathrm{N}}$ values of trace elements were presented in Table 5. The data indicated that most of the study area were slightly contaminated by trace elements. It was worth noting that S6 and S12 sampling sites were moderately contaminated. The S6 sampling points was located in the buffer zone of the reserve, which was a pasture in autumn and winter. Therefore, grazing was a factor affecting the environmental quality.

From the analysis results of risk assessment, it could be seen that most of the soils in the study area were at or below the moderate risk. Only a few sampling sites reached high risk for $\mathrm{Hg}$ or $\mathrm{Cr}$ or $\mathrm{Cd}$, which was due to serious human activities in these sites.

\subsection{Chemical speciation of heavy metals}

The chemical activity, mobility, bioavailability of heavy metals in the environment and their impact on ecosystem or organism couldn't be well explained only based on the total amount of elements, therefore, the present study examined the different chemical forms of heavy metals in soil samples through the Tessier extraction procedure aside from determining the total concentration. The results were shown in the Figure 4.

Exchangeable state referred to the part of metal that was not specifically adsorbed on the surface of soil colloid, but also easily absorbed by plant roots. Among the eight metals, the largest proportion of exchangeable state to total value was $\mathrm{Pb}$, and they were in the decreasing order of $\mathrm{Pb}(20.58 \%)>\mathrm{Mn}$ $(9.15 \%)>\mathrm{Cd}(6.59 \%)>\mathrm{Cu}(3.96 \%)>\mathrm{Cr}(3.49 \%)>\mathrm{Zn}(2.50 \%)>\mathrm{As}(0.05 \%)>\mathrm{Hg}(0.03 \%)$. The activity of $\mathrm{Pb}$ was obviously higher than that of other metals, indicating that $\mathrm{Pb}$ had a strong contribution from 
anthropogenic source in soils and a high probability transferring from soil to plants and underground water (Ma and Rao, 1997; Kaasalainen and Yli-Halla, 2003). The activity of As and Hg was very low, indicating that the impact of the two heavy metals on the environment was limited. The results were different from the BCFs analyzed above, which might be due to the low content of heavy metals in the soil and the limited absorption of plants, so even though the exchangeable metal content was high, the metal content absorbed by plants was still small due to the low enrichment ability of plants. For example, the exchangeable state content of $\mathrm{Pb}$ accounted for $20.58 \%$ of the total value, but the BCF value was 0.021 , while the BCF value of $\mathrm{Hg}$ was the largest $(0.471)$, but the exchangeable state content of $\mathrm{Hg}$ only accounted for $0.03 \%$ of the total value. It made the quality of herbage in the study area not at risk. However, it was still necessary to detect the exogenous introduction of heavy metals, especially $\mathrm{Pb}$ and $\mathrm{Hg}$.

As shown in the Figure 4, in terms of chemical form distribution, the metals studied could be divided into three categories. $\mathrm{Hg}$ and As were mainly in the form of residue, organic matter and iron manganese oxide (94.75\% and $92.63 \%$, respectively), indicating that the bioavailability and mobility of these two heavy metals were limited. The residue, organic matter and iron manganese oxide of $\mathrm{Cu}, \mathrm{Zn}$ and $\mathrm{Cr}$ accounted for $86.57 \%, 88.8 \%$ and $87.01 \%$ of the total value, respectively. These three metals mainly existed in stable form, but the proportion of this form was significantly lower than $\mathrm{Hg}$ and $\mathrm{As}$. $\mathrm{Pb}, \mathrm{Cd}$ and $\mathrm{Mn}$ were the most environmentally risky metals, and their exchangeable and carbonate bound states accounted for $35.65 \%, 44.59 \%$ and $25.09 \%$ of the total values, respectively, and it confirmed the strong contribution of anthropogenic pollution to their accumulation.

\section{Conclusions}

Due to the differences in microclimatic and terrain factors and human activities, some physicochemical properties of the grassland soils in the northeast of Tibet Plateau had a significant linear relationship with elevation, and $\mathrm{Hg}, \mathrm{As}, \mathrm{Zn}, \mathrm{Pb}, \mathrm{Cr}, \mathrm{Mn}$ in soils also showed a linear relationship with elevation, but the relationship between $\mathrm{Cu}, \mathrm{Cd}$ and elevation tends to be quadratic. Trace elements content in soil were affected by certain human activities, but they did not cause serious ecological problems risk, and heavy metals in herbage were still at a safe level. The analysis of soil trace element speciation showed that the active chemical form of $\mathrm{Hg}, \mathrm{As}, \mathrm{Cu}, \mathrm{Zn}, \mathrm{Cr}$ was low, which did not pose obvious ecological risk, but the activity of $\mathrm{Pb}, \mathrm{Cd}, \mathrm{Mn}$ was higher.

\section{Declarations}

\section{Ethics approval and consent to participate}

Not applicable

\section{Consent for publication}

Not applicable 
Availability of data and materials

The datasets used or analysed during the current study are available from the corresponding author on reasonable request.

\section{Competing interests}

The authors declare that they have no competing interests.

\section{Funding}

The National Key Research and Development Program of China (2018YFC1802905)

\section{Authors' contributions}

Qianfang Yang completed sample processing, analyzed and interpreted the data, and was a major contributor in writing the manuscript. Shengli Wang and Zhongren Nan provided the experimental conditions and funds, and directed the experiment and designed the framework of the paper. Cuicui Zhao gave guidance on grammar and content. All authors read and approved the final manuscript.

\section{Acknowledgements}

The author thanks the National Key Research and Development Program of China (2018YFC1802905) for its funding.

\section{References}

1. Ali S, Begum F, Hayat R, Bohannan BJM (2017) Variation in soil organic carbon stock in different land uses and altitudes in Bagrot Valley, Northern Karakoram. Acta Agr Scand B-S P 67:551-561. https://doi.org/10.1080/09064710.2017.1317829

2. Ali S, Hussain I, Hussain S, Hussain A, Ali H, Ali M (2019) Effect of Altitude on Forest Soil Properties at Northern Karakoram. Eurasian Soil Sci 52:1159-1169. https://doi.org/10.1134/S1064229319100120

3. Alloway BJ (1995) The origins of heavy metals in soils. In: Alloway BJ (ed) Heavy Metals in Soils. Chapman and Hall, London, pp 38-57

4. Badr N, Fawzy M, Al-Qahtani KH (2012) Phytoremediation: An ecological solution to heavy-metalpolluted soil and evaluation of plant removal ability. World Appl Sci J 16(9):1292-1301

5. Bergamaschi L, Rizzio E, Valcuvia MG, Verza G, Profumo A, Gallorini M (2002) Determination of trace elements and evaluation of their enrichment factors in Himalayan lichens. Environ Pollut 120:137144. https://doi.org/10.1016/S0269-7491(02)00138-0

6. Blaser P, Zimmermann S, Luster J, Shotyk W (2000) Critical examination of trace element enrichments and depletions in soils: $\mathrm{As}, \mathrm{Cr}, \mathrm{Cu}, \mathrm{Ni}, \mathrm{Pb}$, and $\mathrm{Zn}$ in Swiss forest soils. Sci Total Environ 
249:257-280. https://doi.org/10.1016/S0048-9697(99)00522-7

7. Boularbah A, Schwartz C, Bitton G, Aboudrar W, Ouhammou A, Morel JL (2006) Heavy metal contamination from mining sites in South Morocco: assessment of metal accumulation and toxicity in plants. Chemosphere 63:811-817. https://doi.org/10.1016/j.chemosphere.2005.07.076

8. Cai Y, Carbrera JC, Geogiadis M, Jayachandran K (2002) Assessment of arsenic mobility in the soils of some golf courses. in South Florida Sci Total Environ 291:123-134.

https://doi.org/10.1016/S0048-9697(01)01081-6

9. Camarero L, Botev I, Muri G, Psenner R, Rose N, Stuchlik E (2009) Trace elements in alpine and arctic lake sediments as a record of diffuse atmospheric contamination across Europe. Freshwater Biol 54:2518-2532

10. Cao J, Wang X, Adamowski J, Biswas A, Liu C, Chang Z, Feng Q (2020) Response of leaf stoichiometry of Oxytropis ochrocephala to elevation and slope aspect. Catena 194. https://doi.org/10.1016/j.catena.2020.104772

11. Chai Y, Guo J, Chai S, Cai J, Xue L, Zhang Q (2015) Source identification of eight heavy metals in grassland soils by multivariate analysis from the Baicheng-Songyuan area, Jilin Province, Northeast China. Chemosphere 134:67-75. https://doi.org/10.1016/j.chemosphere.2015.04.008

12. Charan G, Bharti VK, Jadhav SE, Kumar S, Angchok D, Acharya S, Kumar P, Srivastava RB (2012) Altitudinal variations in carbon storage and distribution patterns in cold desert high altitude region of India. Afr J Agric Res 7:6313-6319

13. CNEMC (The Chinese Environmental Monitoring Centre) (1990) The Background Values of Soil Elements in China. Chinese Environment Science Press, Beijing (in Chinese)

14. CNEPA (National Environmental Protection Agency of China) (1995) Environmental Quality Standard for Soils (GB 15618-1995). Beijing (in Chinese)

15. CNSBQTS (China State Bureau of Quality and Technical Supervision) (2017) National Standard of the People's Republic of China - Hygienical Standard for Feeds (GB 13078-2017). Beijing (in Chinese)

16. Cong Z, Kang S, Zhang Y, Gao S, Wang Z, Liu B, Wan X (2015) New insights into trace element wet deposition in the Himalayas: amounts, seasonal patterns, and implications. Environ Sci Pollut Res 22:2735-2744. https://doi.org/10.1007/s11356-014-3496-1

17. Damiani V, Baudo R, De Rosa S, De Simone R, Ferretti O, Izzo G, Serena F (1987) A case study: bay of Pozzuoli (Gulf of Naples, Italy). Hydrobiology 149:201-211. https://doi.org/10.1007/BF00048661

18. Dong S, Jiang Y, Liu Q, Huang X (2004) Effect of altitudinal gradient on yield and quality of subalpine meadow on the Xiaowutai Mountain in northern China. Can J Plant Sci 84:529-531. https://doi.org/10.4141/P03-001

19. Gaston KJ (2000) Global patterns in biodiversity. Nature 405:220-226. https://doi.org/10.1038/35012228

20. Gawryluk A, Wyłupek T, Wolański P (2020) Assessment of $\mathrm{Cu}, \mathrm{Pb}$ and $\mathrm{Zn}$ content in selected species of grasses and in the soil of the roadside embankment. Ecol Evol 10:9841-9852. 
https://doi.org/10.1002/ece3.6627

21. González ZI, Krachler M, Cheburkin AK, Shotyk W (2006) Spatial distribution of natural enrichments of arsenic, selenium, and uranium in a minerotrophic peatland, Gola di Lago, Canton Ticino, Switzerland Environ Sci Technol 40,6568-6574. https://doi.org/ 10.1021/es061080v

22. Grigal DF (2002) Inputs and outputs of mercury from terrestrial watersheds: a review. Environ Rev 10:1-39. https://doi.org/10.1139/A01-013

23. Hadjigeorgiou I, Osoro K, Fragoso de Almeida JP, Molle G (2005) Southern European grazing lands: Production, environmental and landscape management aspects. Livestock Production Science 96:51-59. https://doi.org/10.1016/j.livprodsci.2005.05.016

24. Hakanson L (1980) An ecological risk index for aquatic pollution control.a sedimentological approach. Water Res 14:975-1001. https://doi.org/10.1016/0043-1354(80)90143-8

25. He X, Hou E, Liu Y, Wen D (2016) Altitudinal patterns and controls of plant and soil nutrient concentrations and stoichiometry in subtropical China. Sci Rep-UK 24261. https://doi.org/10.1038/srep24261

26. Holechek JL, Pieper RD, Herbel CH (2010) Range management principles and practices. Sixth edition. Prentice-Hall, Upper Saddle River

27. Hou Q, Yang Z, Ji J, Yu T, Chen G, Li J, Xia X, Zhang M, Yuan X (2014) Annual net input fluxes of heavy metals of the agro-ecosystem in the Yangtze River delta, China. J Geochem Explor 139:68-84. https://doi.org/10.1016/j.gexplo.2013.08.007

28. Hovmand MF, Kemp K, Kystol J, Johnsen I, Riis-Nielsen T, Pacyna JM (2013) Atmospheric heavy metal deposition accumulated in rural forest soils of southern Scandinavia. Environ Pollut 155:537541. https://doi.org/10.1016/j.envpol.2008.01.047

29. Kaasalainen M, Yli-Halla M (2003) Use of sequential extraction to assess metal partitioning in soils. Environ Pollut 126:225-233. https://doi.org/10.1016/S0269-7491(03)00191-X

30. Kabata-Pendias A, Pendias H,. (., ). ; London UK (2001) Trace elements in soils and plants, 3rd edn. Boca Raton, FL, New York: CRC, pp 1-403

31. Kang S, Zhang Q, Kaspari S, Qin D, Cong Z, Ren J, Mayewski PA (2007) Spatial and seasonal variations of elemental composition in Mt. Everest (Qomolangma) snow/firn. Atmos Environ 41:7208-7218. https://doi.org/10.1016/j.atmosenv.2007.05.024

32. Khan S, Cao Q, Zheng YM, Huang YZ, Zhu YG (2008) Health risks of heavy metals in contaminated soils and food crops irrigated with wastewater in Beijing, China. Environ Pollut 152:686-692. https://doi.org/10.1016/j.envpol.2007.06.056

33. Kismányoky T, Tóth Z (2010) Effect of mineral and organic fertilization on soil fertility as well as on the biomass production and $\mathrm{N}$ utilization of winter wheat (Triticum aestivum L.) in a long-term cereal crop rotation experiment (IOSDV). Arch Agron Soil Sci 56(4):473-479.

https://doi.org/10.1080/03650340903296819

34. Li Y, Wang S, Zhang Q, Zang F, Nan Z, Sun H, Huang W, Bao L (2018) Accumulation, interaction and fractionation of fluoride and cadmium in sierozem and oilseed rape (Brassica napus $L$.) in northwest 
China. Plant Physiol Biochem 127:457-468. https://doi.org/10.1016/j.plaphy.2018.04.017

35. Li Y, Wang S, Nan Z, Sun Z, Zhang H, Huang Q, Bao W L (2019) Accumulation, fractionation and health risk assessment of fluoride and heavy metals in soil-crop systems in northwest China. Sci Total Environ 663:307-314. https://doi.org/10.1016/j.scitotenv.2019.01.257

36. Lu R (2000) Analysis Methods of Soil Agricultural Chemistry. China Agricultural Science and Technology Publishing House, Beijing (in Chinese)

37. Luo X, Yu S, Zhu Y, Li D (2012) Trace metal contamination in urban soils of China. Sci Total Environ 421:17-30. https://doi.org/10.1016/j.scitotenv.2011.04.020

38. Magnani A, Ajmone-Marsan F, D'Amico M, Balestrini R, Viviano G, Salerno F, Freppaz M (2018) Soil properties and trace elements distribution along an altitudinal gradient on the southern slope of $\mathrm{Mt}$. Everest Nepal Catena 162:61-71. https://doi.org/10.1016/j.catena.2017.11.015

39. Ma LQ, Rao GN (1997) Chemical fractionation of cadmium, copper, nickel, and zinc in contaminated soils. J Environ Qual 26:259-264. https://doi.org/10.2134/jeq1997.00472425002600010036x

40. Martin AP, Turnbull RE, Rissmann CW, Rieger P (2017) Heavy metal and metalloid concentrations in soils under pasture of southern New Zealand. Geoderm Region 11:18-27. https://doi.org/10.1016/j.geodrs.2017.08.005

41. McGee EJ, Vallejo V. R., 1996. Long-range transport and soil interception of atmophile elements on a transect across the Pyrenees. In: Proceedings of EUROTRAC Symposium. 96, 307-314

42. McLaughlin MJ, Hamon RE, McLaren RG, Speir TW, Rogers SL (2000) Review: a bioavailability-based rationale for controlling metal and metalloid contamination of agricultural land in Australia and New Zealand. Soil Res 38(6):1037-1086. https://doi.org/10.1071/SR99128

43. Mulligan C, Yong R, Gibbs B (2001) Remediation technologies for metal-contaminated soils and groundwater: an evaluation. Eng Geol 60(1):193-207. https://doi.org/10.1016/S00137952(00)00101-0

44. Nziguheba G, Smolders E (2007) Inputs of trace elements in agricultural soils via phosphate fertilizers in European countries. Sci Total Environ 390:53-57. https://doi.org/10.1016/j.scitotenv.2007.09.031

45. Oliva SR, Espinosa AJF (2007) Monitoring of heavy metals in topsoils, atmospheric particles and plant leaves to identify possible contamination sources. Microchem J 86:131-139. https://doi.org/10.1016/j.microc.2007.01.003

46. Parmesan C (2006) Ecological and evolutionary responses to recent climate change. Annu Rev Ecol Evol S 37:637-669. https://doi.org/10.1146/annurev.ecolsys.37.091305.110100

47. Peralta-Videa JR, Lopez ML, Narayan M, Saupe G, Gardea-Torresdey J (2009) The biochemistry of environmental heavy metal uptake by plants: implications for the food chain. Int J Biochem Cell B 41(8):1665-1677. https://doi.org/10.1016/j.biocel.2009.03.005

48. Qin Y, Feng Q, Holden N, Cao J (2016) Variation in soil organic carbon by slope aspect in the middle of the Qilian Mountains in the upper Heihe River Basin, China. Catena 147:308-314. https://doi.org/10.1016/j.catena.2016.07.025 
49. Quenea K, Lamy I, Winterton P, Bermond A, Dumat C (2009) Interactions between metals and soil organic matter in various particle size fractions of soil contaminated with waste water. Geoderma 149:217-223. https://doi.org/10.1016/j.geoderma.2008.11.037

50. Reiners WA, Marks RH, Vitousek PM (1975) Heavy metals in alpine and sub-alpine soils of New Hampshire. Oikos 26:264-275

51. Roberts TL, Bettany JR (1985) The Influence of Topography On the Nature and Distribution of Soil Sulfur Across a Narrow Environmental Gradient. Can J Soil Sci 65:419-434. https://doi.org/10.4141/cjss85-046

52. Roukos C, Koutsoukis C, Akrida DK, Karatassiou M, Demertzis G, P., Kandrelis S (2017) The effect of altitudinal zone on soil properties, species composition and forage production in subalpine grassland in northwest Greece. Appl Ecol Env Res 15:609-626.

http://dx.doi.org/10.15666/aeer/1501_609626

53. Roukos C, Papanikolaou C, Mountousis I, Kandrelis S, Chatzitheodoridis F (2011) Soil property variations in relation to plant community and altitudinal zone in the rangelands of Epirus. Greece Bulg J Agric Sci 17:806-815

54. Salerno F, Guyennon N, Thakuri S, Viviano G, Romano E, Vuillermoz E, Cristofanelli P, Stocchi P, Agrillo G, Ma Y, Tartari G (2015) Weak precipitation, warm winters and springs impact glaciers of south slopes of Mt. Everest (central Himalaya) in the last 2 decades (1994-2013). Cryosphere 9:12291247. http://dx.doi.org/10.5194/tc-9-1229-2015

55. Tessier A, Campbell PGC, Bisson M (1979) Sequential extraction procedure for the speciation of particulate trace metals. Anal Chem 51:844-851. http://dx.doi.org/10.1021/ac50043a017

56. Tomlinson DL, Wilson JG, Harris CR, Jeffrey DW (1980) Problem in Heavy Metals in Estuaries and the formation of a pollution index. Helgol Wiss Meeresunlter 33:566-575

57. Tyler G (2004) Vertical distribution of major, minor, and rare elements in a Haplic Podzol. Geoderma 119:277-290. https://doi.org/10.1016/j.geoderma.2003.08.005

58. Vu CT, Lin C, Shern C, Yeh G, Le VG, Tran HT (2017) Contamination, ecological risk and source apportionment of heavy metals in sediments and water of a contaminated river in Taiwan. Ecol Indic 82:32-42. https://doi.org/10.1016/j.ecolind.2017.06.008

59. Williams J, Antoine A, J (2020) Evaluation of the elemental pollution status of Jamaican surface sediments using enrichment factor, geoaccumulation index, ecological risk and potential ecological risk index. Mar Pollut Bull 157:111288. https://doi.org/10.1016/j.marpolbul.2020.111288

60. Williams SE, Bolitho EE, Fox S (2003) Climate change in Australian tropical rainforests: an impending environmental catastrophe. P Roy Soc B-Biol Sci 270:1887-1892.

http://dx.doi.org/10.1098/rspb.2003.2464

61. Yang J, Chen L, Liu L, Shi W, Meng X (2014) Comprehensive risk assessment of heavy metals in lake sediment from public parks in Shanghai. Ecotoxicol Environ Saf 102:129-135.

https://doi.org/10.1016/j.ecoenv.2014.01.010 
62. Yao X, Yang N, Li Y, Bian H, Ding X, Zhou Q (2019) Bioaccumulation in Miscanthus sacchariflorus grown on cadmium-contaminated sediments: a comparative study between submerged and nonsubmerged environments. Int J Phytoremediat 21(3):240-245.

https://doi.org/10.1080/15226514.2018.1524844

63. Yuan P, Wu X, Xia Y, Peng C, Tong H, Liu J, Jiang L, Wang X (2020) Spatial and seasonal variations and risk assessment for heavy metals in surface sediments of the largest river-embedded reservoir in China. Environ Sci Pollut R. https://doi.org/10.1007/s11356-020-09868-w

64. Zhang C, Liu G, Xue S, Sun C (2013) Soil organic carbon and total nitrogen storage as affected by land use in a small watershed of the Loess Plateau, China. Eur J Soil Biol 54:16-24. https://doi.org/10.1016/j.ejsobi.2012.10.007

65. Zhang Q, Wang S, Nan Z, Li Y, Zang F (2018) Accumulation, fractionation, and risk assessment of mercury and arsenic in the soil-wheat system from the wastewater-irrigated soil in Baiyin, northwest China. Environ Sci Pollut R 25:14856-14867. https://doi.org/10.1007/s11356-018-1641-y

66. Zhao L, Xu Y, Hou H, Shangguan Y, Li F (2014) Source identification and health risk assessment of metals in urban soils around the Tanggu chemical industrial district. Tianjin China Sci Total Environ 468:654-662. https://doi.org/10.1016/j.scitotenv.2013.08.094

\section{Tables}

Table 1

Descriptive statistics of heavy metals of plant samples

\begin{tabular}{cccccccc}
\hline Variable & Unit & Min & Max & Mean & SD $^{\mathrm{a}}$ & $\mathrm{CV}^{\mathrm{b}}$ & Hygienic standard $^{\mathrm{C}}$ \\
\hline $\mathrm{Hg}$ & $\mu \mathrm{g} \mathrm{kg}^{-1}$ & 12.471 & 21.684 & 17.085 & 2.759 & $16 \%$ & 100 \\
$\mathrm{As}$ & $\mu \mathrm{g} \mathrm{kg}^{-1}$ & 134.524 & 541.966 & 250.394 & 120.189 & $48 \%$ & 4000 \\
$\mathrm{Cu}$ & $\mathrm{mg} \mathrm{kg}^{-1}$ & 4.864 & 8.902 & 6.156 & 1.242 & $20 \%$ & \\
$\mathrm{Zn}$ & $\mathrm{mg} \mathrm{kg}^{-1}$ & 4.815 & 49.805 & 24.574 & 11.372 & $46 \%$ & \\
$\mathrm{~Pb}$ & $\mathrm{mg} \mathrm{kg}^{-1}$ & 0.164 & 1.625 & 0.737 & 0.395 & $54 \%$ & 30 \\
$\mathrm{Cd}$ & $\mathrm{mg} \mathrm{kg}^{-1}$ & 0.057 & 0.159 & 0.091 & 0.030 & $33 \%$ & 1 \\
$\mathrm{Cr}$ & $\mathrm{mg} \mathrm{kg}^{-1}$ & 0.232 & 1.140 & 0.567 & 0.257 & $45 \%$ & 5 \\
$\mathrm{Mn}$ & $\mathrm{mg} \mathrm{kg}^{-1}$ & 48.113 & 124.313 & 76.561 & 21.123 & $28 \%$ & \\
\hline
\end{tabular}

${ }^{\mathrm{a}}$ Coefficient of Variation.

b Standard deviation.

${ }^{\mathrm{C}}$ Hygienical Standard for Feeds (CNSBQTS, 2017) (in Chinese).

Table 2

Descriptive statistics of heavy metals and physicochemical properties of surface soils. 


\begin{tabular}{|c|c|c|c|c|c|c|c|c|c|}
\hline Variable & Unit & Min & Max & Mean & SD & $\mathrm{CV}$ & Soil environmental quality ${ }^{\mathrm{a}}$ & Soil background ${ }^{\mathrm{b}}$ & $\mathrm{BCF}^{\mathrm{C}}$ \\
\hline $\mathrm{pH}$ & & 7.9 & 8.2 & 8.1 & 0.1 & $0.9 \%$ & 8.5 & & \\
\hline $\mathrm{EC}$ & $\mu \mathrm{S} \mathrm{cm} \mathrm{cm}^{-1}$ & 165.00 & 282.00 & 215.15 & 36.57 & $17 \%$ & & & \\
\hline $\mathrm{CaCO}_{3}$ & $\mathrm{~g} \mathrm{~kg}^{-1}$ & 43.4 & 183.5 & 70.6 & 34.3 & $49 \%$ & & & \\
\hline $\mathrm{OM}$ & $\mathrm{g} \mathrm{kg}^{-1}$ & 48.8 & 160.8 & 88.7 & 38.1 & $43 \%$ & 26.5 & & \\
\hline TKN & $\mathrm{g} \mathrm{kg}^{-1}$ & 1.29 & 9.61 & 4.78 & 2.65 & $55 \%$ & & & \\
\hline $\mathrm{TP}$ & $\mathrm{g} \mathrm{kg}^{-1}$ & 0.32 & 0.80 & 0.58 & 0.13 & $22 \%$ & & & \\
\hline $\mathrm{Hg}$ & $\mu \mathrm{kg}^{-1}$ & 28.1 & 60.8 & 40.9 & 10.8 & $26 \%$ & 150 & 20.00 & 0.417 \\
\hline As & $\mathrm{mg} \mathrm{kg}^{-1}$ & 11.0 & 15.4 & 13.2 & 1.3 & $10 \%$ & 15 & 12.60 & 0.019 \\
\hline $\mathrm{Cu}$ & $\mathrm{mg} \mathrm{kg}^{-1}$ & 30.5 & 39.0 & 34.0 & 2.1 & $6 \%$ & 35 & 24.10 & 0.181 \\
\hline $\mathrm{Zn}$ & $\mathrm{mg} \mathrm{kg}^{-1}$ & 56 & 116 & 81 & 16 & $19 \%$ & 100 & 68.50 & 0.302 \\
\hline $\mathrm{Pb}$ & $\mathrm{mg} \mathrm{kg}^{-1}$ & 15.6 & 50.2 & 34.8 & 7.3 & $21 \%$ & 35 & 18.80 & 0.021 \\
\hline $\mathrm{Cd}$ & $\mathrm{mg} \mathrm{kg}^{-1}$ & 0.150 & 0.376 & 0.232 & 0.057 & $25 \%$ & 0.2 & 0.12 & 0.393 \\
\hline $\mathrm{Cr}$ & $\mathrm{mg} \mathrm{kg}^{-1}$ & 100.0 & 218.0 & 136.6 & 31.6 & $23 \%$ & 90 & 70.20 & 0.004 \\
\hline $\mathrm{Mn}$ & $\mathrm{mg} \mathrm{kg}^{-1}$ & 585 & 1071 & 876 & 159 & $18 \%$ & & 653.00 & 0.087 \\
\hline
\end{tabular}

a Grade I of environmental quality standard for soils (CNEPA, 1995) (in Chinese).

b The Backgrounds of Gansu Province soil (CNEMC, 1990) (in Chinese).

${ }^{\mathrm{c}}$ Bioaccumulation Factor.

\section{Table 3}

Pearson correlations between heavy metal concentrations and physiochemical properties of surface soils.

\begin{tabular}{|c|c|c|c|c|c|c|c|c|c|c|c|c|c|c|}
\hline Variable & $\mathrm{pH}$ & EC & $\mathrm{CaCO}_{3}$ & $\mathrm{OM}$ & TKN & $\mathrm{TP}$ & $\mathrm{Hg}$ & As & $\mathrm{Cu}$ & $\mathrm{Zn}$ & $\mathrm{Pb}$ & $\mathrm{Cd}$ & $\mathrm{Cr}$ & $\mathrm{Mn}$ \\
\hline $\mathrm{pH}$ & 1 & & & & & & & & & & & & & \\
\hline EC & -0.295 & 1 & & & & & & & & & & & & \\
\hline $\mathrm{CaCO}_{3}$ & $0.539^{*}$ & -0.238 & 1 & & & & & & & & & & & \\
\hline OC & -0.443 & 0.482 & -0.254 & 1 & & & & & & & & & & \\
\hline $\mathrm{TKN}$ & $-0.589^{*}$ & 0.151 & -0.267 & 0.210 & 1 & & & & & & & & & \\
\hline $\mathrm{TP}$ & -0.285 & 0.318 & 0.058 & 0.047 & $0.612^{*}$ & 1 & & & & & & & & \\
\hline $\mathrm{Hg}$ & -0.236 & $0.528^{*}$ & -0.214 & 0.351 & 0.242 & 0.224 & 1 & & & & & & & \\
\hline As & 0.364 & $-0.600^{*}$ & 0.366 & $-0.546^{*}$ & -0.182 & -0.320 & -0.266 & 1 & & & & & & \\
\hline $\mathrm{Cu}$ & 0.059 & 0.255 & -0.296 & -0.426 & -0.049 & 0.121 & 0.294 & -0.228 & 1 & & & & & \\
\hline $\mathrm{Zn}$ & -0.229 & -0.281 & 0.103 & -0.194 & -0.062 & -0.034 & -0.137 & -0.029 & -0.212 & 1 & & & & \\
\hline $\mathrm{Pb}$ & $0.522^{*}$ & -0.354 & 0.268 & $-0.742^{* *}$ & -0.154 & -0.116 & -0.260 & 0.426 & 0.097 & 0.147 & 1 & & & \\
\hline $\mathrm{Cd}$ & 0.342 & -0.031 & $0.656^{* *}$ & -0.110 & 0.108 & -0.001 & 0.150 & 0.247 & -0.087 & -0.076 & 0.283 & 1 & & \\
\hline $\mathrm{Cr}$ & -0.093 & 0.295 & -0.341 & 0.164 & 0.399 & 0.158 & 0.101 & -0.341 & 0.125 & -0.197 & 0.185 & 0.216 & 1 & \\
\hline $\mathrm{Mn}$ & 0.125 & 0.403 & -0.202 & -0.353 & 0.265 & 0.335 & 0.086 & -0.230 & 0.462 & -0.077 & 0.425 & 0.074 & 0.485 & 1 \\
\hline
\end{tabular}

* Correlation is significant at the 0.05 level (2 tailed).

** Correlation is significant at the 0.01 level (2 tailed). 
Geoaccumulation indexes $\left(\mathrm{I}_{\text {geo }}\right)$ of the heavy metals in the soils.

\begin{tabular}{|c|c|c|c|c|c|c|c|c|c|c|c|c|c|c|c|c|}
\hline \multirow{2}{*}{$\begin{array}{c}\text { Sample } \\
\text { Sites }\end{array}$} & \multicolumn{2}{|c|}{$\mathrm{Hg}$} & \multicolumn{2}{|c|}{ As } & \multicolumn{2}{|c|}{$\mathrm{Cu}$} & \multicolumn{2}{|c|}{$\mathrm{Zn}$} & \multicolumn{2}{|c|}{$\mathrm{Pb}$} & \multicolumn{2}{|c|}{$\mathrm{Cd}$} & \multicolumn{2}{|c|}{$\mathrm{Cr}$} & \multicolumn{2}{|c|}{$\mathrm{Mn}$} \\
\hline & I & & 1 & & EI & e & e & & 1 Ige & e & el Ige & eve & {$[119$} & eveve & 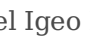 & el \\
\hline S1 & 0.10 & 1 & -0.37 & 0 & -0.09 & 0 & -0.19 & 0 & 0.16 & 1 & -0.18 & 0 & 0.18 & 1 & -0.50 & 0 \\
\hline S2 & 0.51 & 1 & -0.52 & 0 & -0.24 & 0 & 0.17 & 1 & 0.03 & 1 & 0.37 & 1 & 0.15 & 1 & -0.64 & 0 \\
\hline S3 & 0.02 & 1 & -0.66 & 0 & 0.02 & 1 & -0.30 & 0 & 0.46 & 1 & 0.48 & 1 & 0.56 & 1 & -0.06 & 0 \\
\hline S4 & 0.60 & 1 & -0.64 & 0 & -0.14 & 0 & -0.48 & 0 & -0.85 & 0 & 0.03 & 1 & 0.00 & 1 & -0.74 & 0 \\
\hline S5 & -0.09 & 0 & -0.42 & 0 & -0.07 & 0 & -0.35 & 0 & 0.32 & 1 & 0.40 & 1 & 0.63 & 1 & 0.13 & 1 \\
\hline S6 & 0.57 & 1 & -0.78 & 0 & -0.20 & 0 & -0.29 & 0 & 0.25 & 1 & 0.71 & 1 & 1.05 & 2 & 0.03 & 1 \\
\hline S7 & 1.02 & 2 & -0.76 & 0 & 0.11 & 1 & -0.27 & 0 & 0.14 & 1 & 0.33 & 1 & 0.50 & 1 & -0.09 & 0 \\
\hline S8 & 0.99 & 1 & -0.41 & 0 & -0.02 & 0 & -0.65 & 0 & 0.29 & 1 & 0.74 & 1 & 0.51 & 1 & 0.09 & 1 \\
\hline S9 & 0.94 & 1 & -0.53 & 0 & -0.08 & 0 & -0.58 & 0 & 0.31 & 1 & 0.21 & 1 & 0.21 & 1 & -0.02 & 0 \\
\hline S10 & 0.37 & 1 & -0.33 & 0 & -0.11 & 0 & -0.89 & 0 & 0.83 & 1 & 0.38 & 1 & 0.60 & 1 & -0.22 & 0 \\
\hline S11 & 0.09 & 1 & -0.53 & 0 & -0.09 & 0 & -0.02 & 0 & 0.21 & 1 & 0.14 & 1 & 0.51 & 1 & -0.18 & 0 \\
\hline S12 & 0.29 & 1 & -0.30 & 0 & -0.14 & 0 & -0.76 & 0 & 0.51 & 1 & 1.06 & 2 & -0.07 & 0 & -0.47 & 0 \\
\hline S13 & 0.37 & 1 & -0.61 & 0 & -0.08 & 0 & -0.23 & 0 & 0.42 & 1 & -0.26 & 0 & 0.30 & 1 & 0.05 & 1 \\
\hline S14 & 0.20 & 1 & -0.50 & 0 & -0.18 & 0 & -0.48 & 0 & 0.47 & 1 & 0.26 & 1 & 0.08 & 1 & -0.25 & 0 \\
\hline S15 & 0.09 & 1 & -0.58 & 0 & -0.07 & 0 & -0.16 & 0 & 0.42 & 1 & 0.26 & 1 & -0.07 & 0 & 0.10 & 1 \\
\hline
\end{tabular}

\section{Table 5}

Contamination factors (CF) of the heavy metals in the soils.

\begin{tabular}{|c|c|c|c|c|c|c|c|c|c|}
\hline \multirow{2}{*}{$\begin{array}{c}\text { Sample } \\
\text { Sites }\end{array}$} & \multicolumn{8}{|c|}{$\mathrm{CF}$} & \multirow[t]{2}{*}{$\mathrm{P}_{\mathrm{N}}$} \\
\hline & $\mathrm{Hg}$ & As & $\mathrm{Cu}$ & $\mathrm{Cd}$ & $\mathrm{Pb}$ & $\mathrm{Cr}$ & $\mathrm{Zn}$ & $\mathrm{Mn}$ & \\
\hline $\mathrm{S} 1$ & 1.61 & 1.16 & 1.41 & 1.32 & 1.68 & 1.70 & 1.32 & 1.06 & 1.56 \\
\hline S2 & 2.13 & 1.05 & 1.28 & 1.94 & 1.53 & 1.67 & 1.69 & 0.97 & 1.86 \\
\hline S3 & 1.53 & 0.95 & 1.52 & 2.09 & 2.06 & 2.22 & 1.22 & 1.43 & 1.94 \\
\hline S4 & 2.28 & 0.96 & 1.36 & 1.54 & 0.83 & 1.50 & 1.07 & 0.90 & 1.85 \\
\hline S5 & 1.41 & 1.12 & 1.43 & 1.98 & 1.87 & 2.32 & 1.18 & 1.64 & 2.00 \\
\hline S6 & 2.23 & 0.87 & 1.31 & 2.46 & 1.79 & 3.12 & 1.23 & 1.53 & 2.54 \\
\hline S7 & 3.04 & 0.89 & 1.62 & 1.89 & 1.66 & 2.12 & 1.24 & 1.41 & 2.47 \\
\hline S8 & 2.98 & 1.13 & 1.48 & 2.51 & 1.84 & 2.14 & 0.96 & 1.60 & 2.47 \\
\hline S9 & 2.89 & 1.04 & 1.42 & 1.74 & 1.86 & 1.73 & 1.01 & 1.48 & 2.35 \\
\hline S10 & 1.94 & 1.19 & 1.39 & 1.95 & 2.67 & 2.27 & 0.81 & 1.29 & 2.24 \\
\hline S11 & 1.59 & 1.04 & 1.41 & 1.66 & 1.74 & 2.14 & 1.48 & 1.32 & 1.87 \\
\hline S12 & 1.84 & 1.22 & 1.36 & 3.13 & 2.14 & 1.43 & 0.89 & 1.09 & 2.50 \\
\hline S13 & 1.94 & 0.98 & 1.42 & 1.25 & 2.00 & 1.84 & 1.28 & 1.55 & 1.79 \\
\hline S14 & 1.72 & 1.06 & 1.32 & 1.80 & 2.07 & 1.58 & 1.07 & 1.26 & 1.80 \\
\hline S15 & 1.59 & 1.01 & 1.43 & 1.80 & 2.00 & 1.42 & 1.35 & 1.61 & 1.78 \\
\hline
\end{tabular}

\section{Table 6}

Potential ecological risk index (RI) of the heavy metals in the soils. 


\begin{tabular}{|c|c|c|c|c|c|c|c|c|}
\hline \multirow{2}{*}{$\begin{array}{c}\text { Sampling } \\
\text { Sites }\end{array}$} & \multicolumn{7}{|c|}{$\mathrm{Er}$} & \multirow[t]{2}{*}{ RI } \\
\hline & $\mathrm{Hg}$ & As & $\mathrm{Cu}$ & $\mathrm{Cd}$ & $\mathrm{Pb}$ & $\mathrm{Cr}$ & $\mathrm{Zn}$ & \\
\hline $\mathrm{S} 1$ & 64.25 & 11.64 & 7.04 & 39.65 & 8.39 & 3.40 & 1.32 & 135.69 \\
\hline $\mathrm{S} 2$ & 85.25 & 10.49 & 6.34 & 58.33 & 7.64 & 3.33 & 1.69 & 173.06 \\
\hline S3 & 61.00 & 9.51 & 7.60 & 62.63 & 10.31 & 4.43 & 1.22 & 156.70 \\
\hline S4 & 91.00 & 9.61 & 6.79 & 46.05 & 4.15 & 3.01 & 1.07 & 161.68 \\
\hline S5 & 56.25 & 11.18 & 7.17 & 59.35 & 9.36 & 4.63 & 1.18 & 149.12 \\
\hline S6 & 89.25 & 8.72 & 6.54 & 73.73 & 8.95 & 6.21 & 1.23 & 194.62 \\
\hline S7 & 121.50 & 8.86 & 8.09 & 56.70 & 8.28 & 4.24 & 1.24 & 208.92 \\
\hline S8 & 119.00 & 11.30 & 7.38 & 75.23 & 9.18 & 4.27 & 0.96 & 227.31 \\
\hline S9 & 115.50 & 10.42 & 7.12 & 52.13 & 9.32 & 3.46 & 1.01 & 198.95 \\
\hline S10 & 77.75 & 11.93 & 6.97 & 58.53 & 13.35 & 4.54 & 0.81 & 173.87 \\
\hline S11 & 63.75 & 10.41 & 7.05 & 49.68 & 8.68 & 4.28 & 1.48 & 145.33 \\
\hline $\mathrm{S} 12$ & 73.50 & 12.22 & 6.79 & 93.90 & 10.67 & 2.85 & 0.89 & 200.82 \\
\hline $\mathrm{S} 13$ & 77.50 & 9.84 & 7.10 & 37.60 & 10.02 & 3.69 & 1.28 & 147.04 \\
\hline S14 & 68.75 & 10.59 & 6.62 & 54.05 & 10.36 & 3.16 & 1.07 & 154.61 \\
\hline S15 & 63.75 & 10.07 & 7.17 & 53.90 & 10.02 & 2.85 & 1.35 & 149.09 \\
\hline
\end{tabular}

Figures 


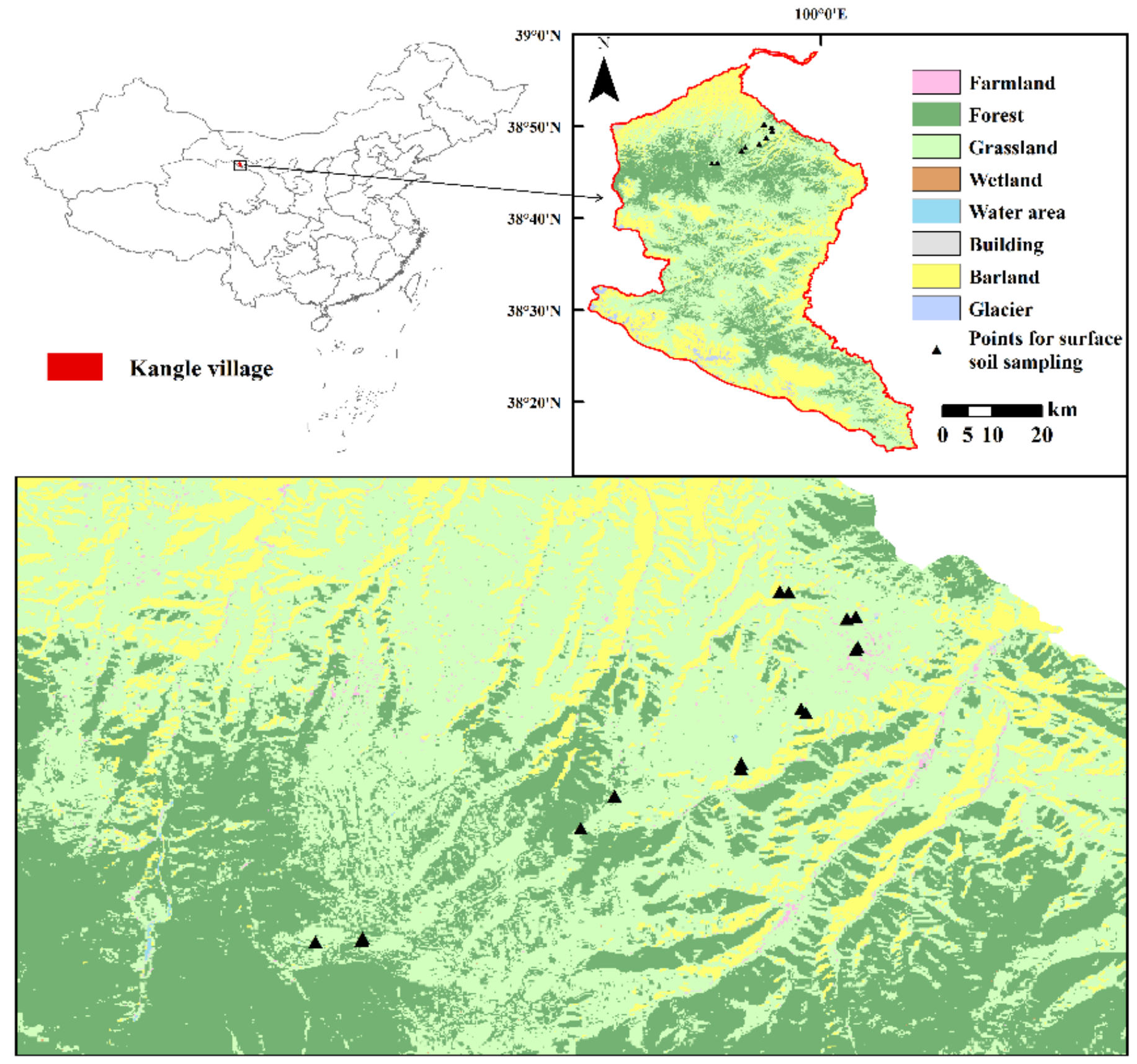

\section{Figure 1}

Soil sampling locations of the study area. Note: The designations employed and the presentation of the material on this map do not imply the expression of any opinion whatsoever on the part of Research Square concerning the legal status of any country, territory, city or area or of its authorities, or concerning the delimitation of its frontiers or boundaries. This map has been provided by the authors. 

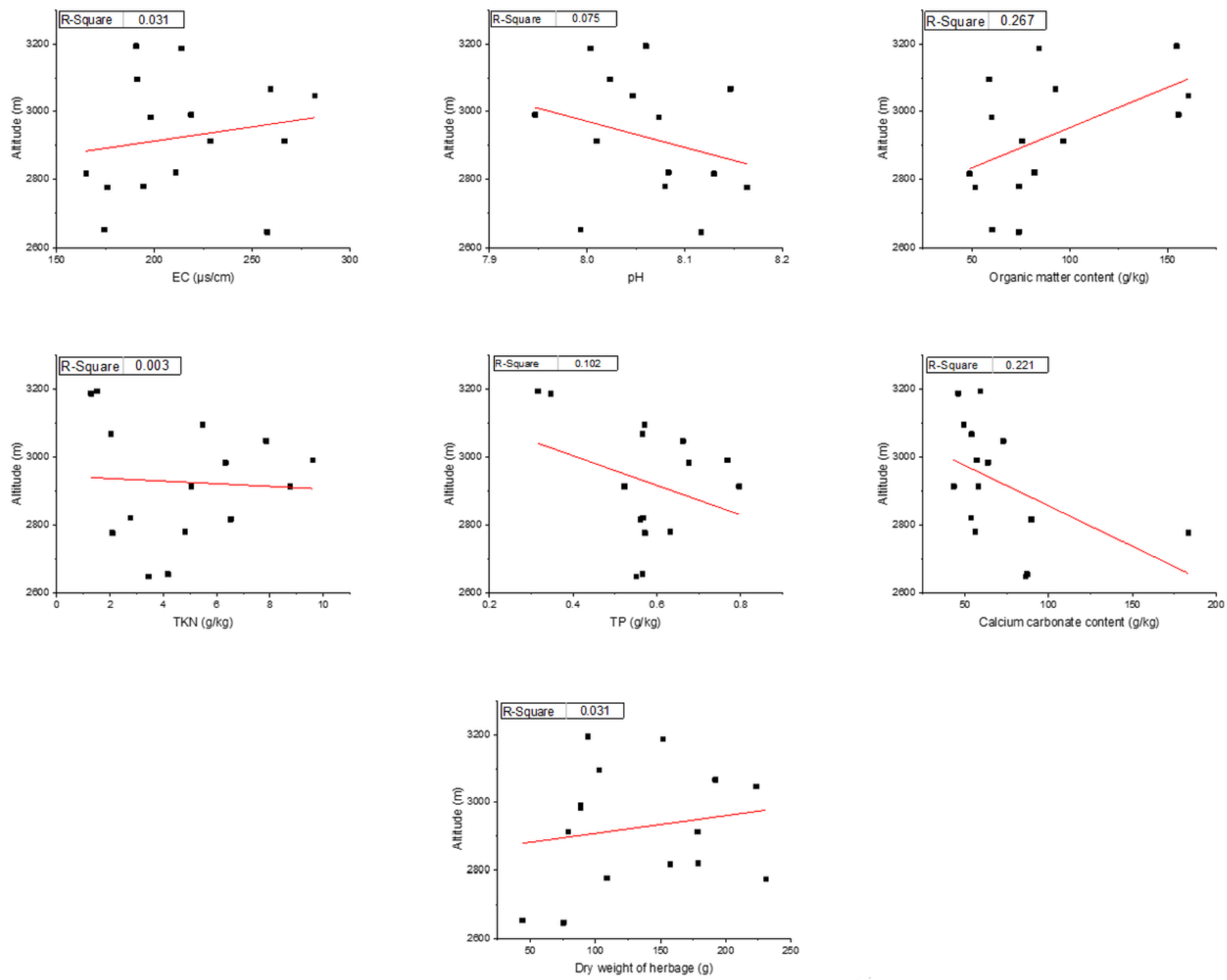

Figure 2

Physicochemical properties of topsoil and biomass of herbage along the altitudinal gradient. 

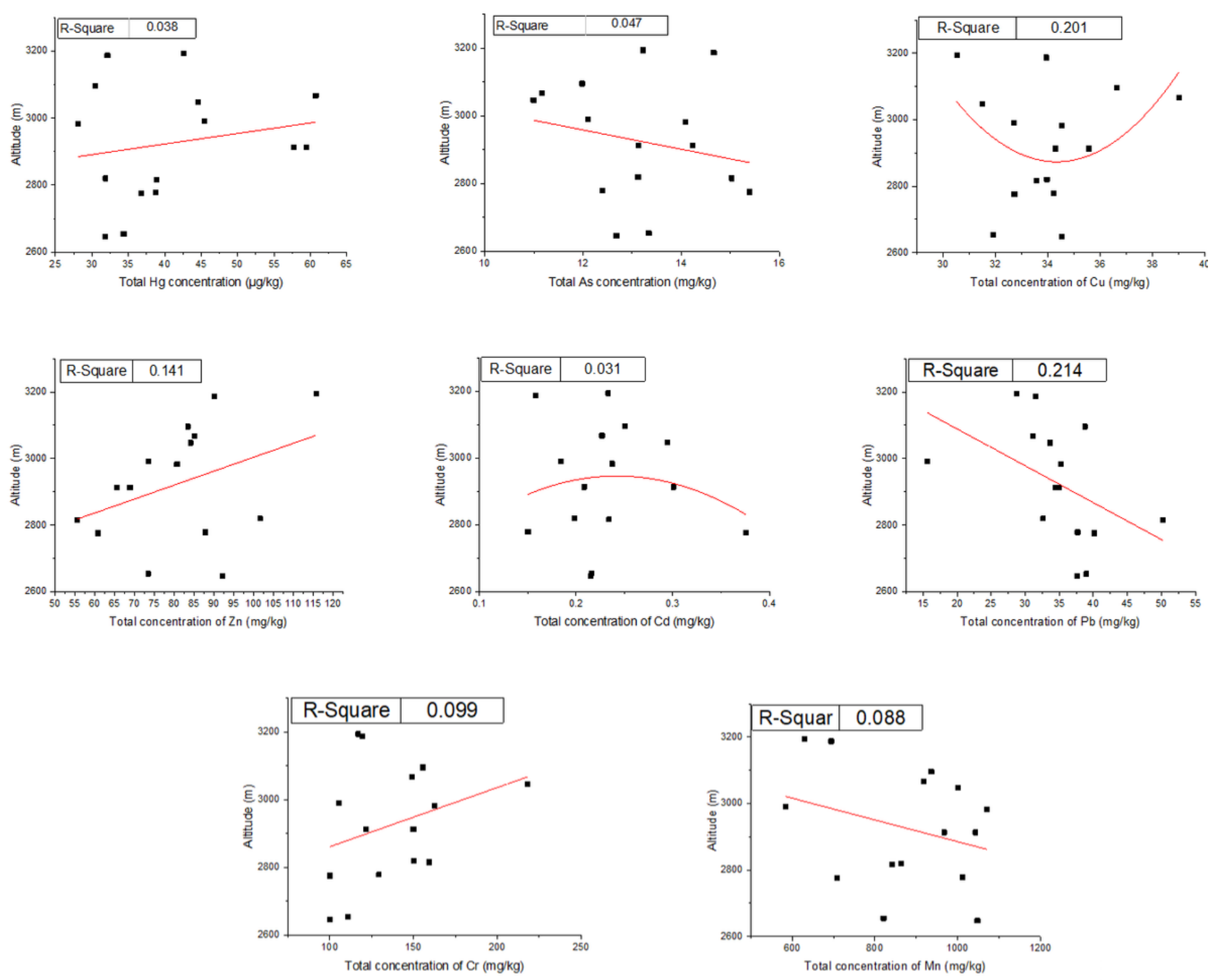

Figure 3

Concentrations of trace elements along the altitudinal gradient. 

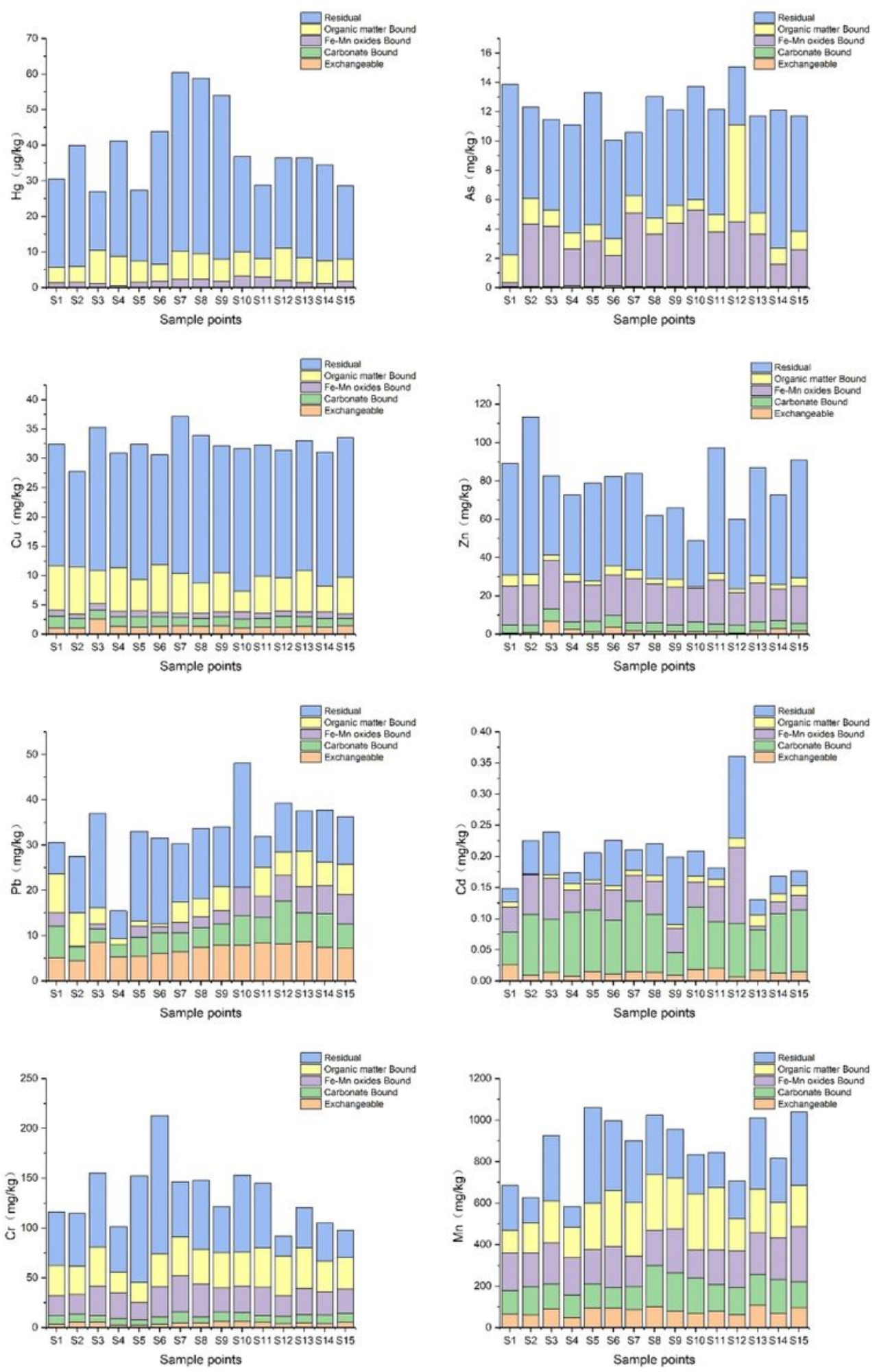

Figure 4

Chemical fractionation of heavy metals in surface soils of the study area.

\section{Supplementary Files}

This is a list of supplementary files associated with this preprint. Click to download. 
- Supplementarymaterial.docx

Page 25/25 